\title{
DO EUROPEAN REAL ESTATE STOCKS HEDGE INFLATION? EVIDENCE FROM DEVELOPED AND EMERGING MARKETS
}

\author{
Chyi Lin LEE ${ }^{a, *}$, Ming-Long LEE ${ }^{b}$ \\ ${ }^{a}$ University of Western Sydney, School of Business, Locked Bag 1797, Penrith, New South Wales 2751, \\ Australia \\ ${ }^{b}$ National Dong Hwa University, Department of Finance, No. 1, Sec. 2, Da Hsueh Rd., Shoufeng, \\ Hualien 97401, Taiwan
}

Received 11 September 2012; accepted 13 March 2013

\begin{abstract}
This study examines the inflation-hedging properties of European real estate stocks in developed and emerging markets over 1990 to 2011. The Fama and Schwert model and a dynamic ordinary least squares (DOLS) regression were employed to study the inflation-hedging characteristics of European real estate stocks over the short run and long run. The empirical results show little inflationhedging ability of European real estate stocks over the short run. Over the long run, developed real estate stocks provide a positive inflation hedge against expected inflation, while no similar evidence is found in the emerging markets. The findings suggest that the inflation-hedging properties of real estate stocks are related to the institutional involvement in the real estate stock markets. The finding could have profound implications to institutional investors.
\end{abstract}

KEYWORDS: Real estate stocks; Inflation-hedging; DOLS; Short-run and long-run; Europe.

REFERENCE to this paper should be made as follows: Lee, C. L.; Lee, M.-L. 2014. Do European real estate stocks hedge inflation? Evidence from developed and emerging markets, International Journal of Strategic Property Management 18(2): 178-197.

\section{INTRODUCTION}

The European debt crisis and the Global Financial Crisis (GFC) have had a strong negative impact on the European economics. In response to the worsening economic climate, a loose monetary policy has been widely implemented by many central banks. Loose monetary policy is adopted by cutting interest rate and providing massive injections of money into economics. This is clearly demonstrated by Fig. 1 in which the European Central Bank has cut the interest rate on the main refinancing operations (MROs) significantly in recent years. A similar trend was also found in the United Kingdom (U.K.). But a continuation of very loose monetary policy could heighten inflation expectation in the long run, particularly during the process of recovery from financial crisis (Kearns et al. 2010). In fact, inflationary pressures have been evident in many European countries in

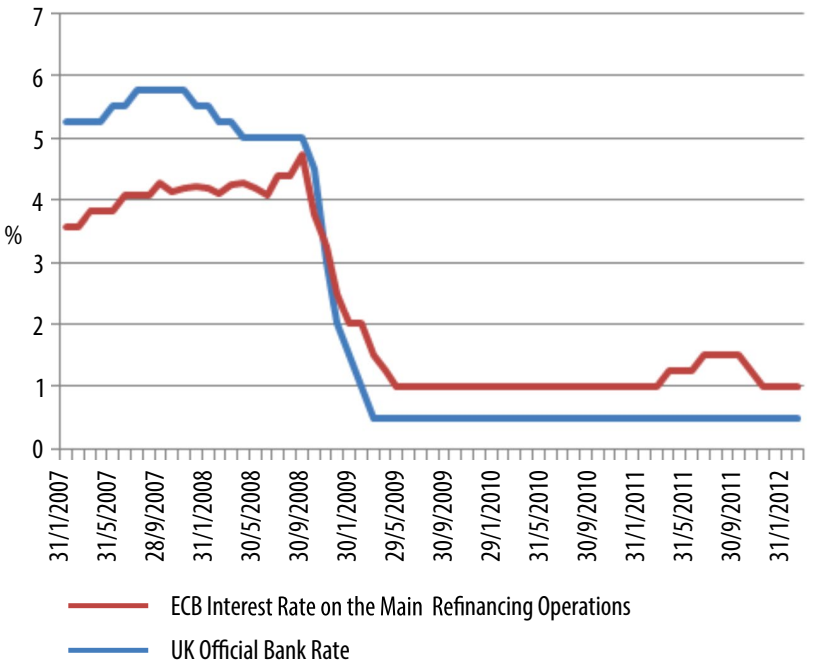

Fig. 1. Interest rates in Europe Sources: Bank of England (2012) and European Central Bank (2012)

\footnotetext{
* Corresponding author. E-mail: chyilin.lee@uws.edu.au
} 
recent years. For instance, as of December 2011, the Eurozone inflation rate was $2.8 \%$, which well above its $2 \%$ target (RREEF 2012).

Many central banks have also acknowledged that a stable and low inflation environment is the overriding goal of monetary policy (Bernanke, Woodford 1997). Moreover, inflation targeting in various forms have been adopted in many countries such as Australia, the UK and Czech Republic (Svensson 1999). Therefore, central banks would adjust their monetary policies (i.e. adjusting the official interest rate) in response to inflation movements. Importantly, the changes will have significant impact on the economy. As highlighted by Svensson (1999), the monetary policy changes will not only affect inflation rates, but also exchange rate movements and nominal wages. As a result, inflation has a significant impact on the economy of a country.

Although many central banks have dedicated to provide a low inflation environment, investors, particularly long-term investors would prefer an asset that provides a complete hedge against inflation. As discussed by Glascock et al. (2002), inflation is a significant determinant in asset returns. Specifically, rational investors want to maintain the same level of real returns or purchasing power. In other words, investment vehicles that will offer protection to wealth will be highly desirable. This feature is of particular interest to sponsors, insurance companies and defined benefit pension funds which have to pay to their members benefits linked to earnings that generally rise with inflation (Glascock et al. 2002; Hoesli et al. 2008). In short, inflation is a key consideration in investment decision making for many institutional investors.

Traditionally, property has been viewed as a good hedge against inflation. In the property literature, direct properties in general represent a good hedge against inflation (Hartzell et al. 1987; Gyourko, Linneman 1988; Glascock et al.
2002). This feature is highly desirable for longrun institutional investors, such as pension funds and insurance companies(Hoesli et al. 2008; Zhang, Ewald 2010). Importantly, this could be one of the main motivations for institutional investors to invest in property (Newell 1996). Nevertheless, some adverse features of direct property investments have limited the possibility for large institutional investors to hold and manage a well-diversified direct property portfolio. These adverse features are large size of investments, the lack of a central market, high transaction costs, low liquidity, the need for local knowledge and management burdens (Seiler et al. 2001; Wilson, Zurbruegg 2003). Thus, real estate stocks emerge as an essential property investment vehicle to overcome these drawbacks. Real estate stocks are securitised forms of real estate. Therefore, securitised real estate, particularly REITs exhibit some unique characteristics compared to general stocks (i.e. high dividend payout). In addition, recent real estate studies have shown a structural change in the securitised real estate market. Importantly, these studies offered evidence to support the notion of securitised real estate behave more like unsecuritised real estate and better linked to real estate fundamentals since 1992 (Clayton, MacKinnon 2003; Lee et al. 2008). In other words, securitised real estate looks less and less like common stocks (Ghosh et al. 1996; Lee, Chiang 2010). Furthermore, the increasing popularity of real estate securities in Europe is also illustrated by Fig. 2. The total market capitalisation of the FTSE/EPRA NAREIT Developed Europe Index has increased considerably from $€ 46.4$ billion in Jan 2009 to $€ 91.9$ billion in April 2012, suggesting that European real estate securities have been widely accepted by investors as an important asset class. To further develop the European securitised real estate markets, futures contracts written on European real estate securities have also been launched in recent years (Lee et al. 2014). All of

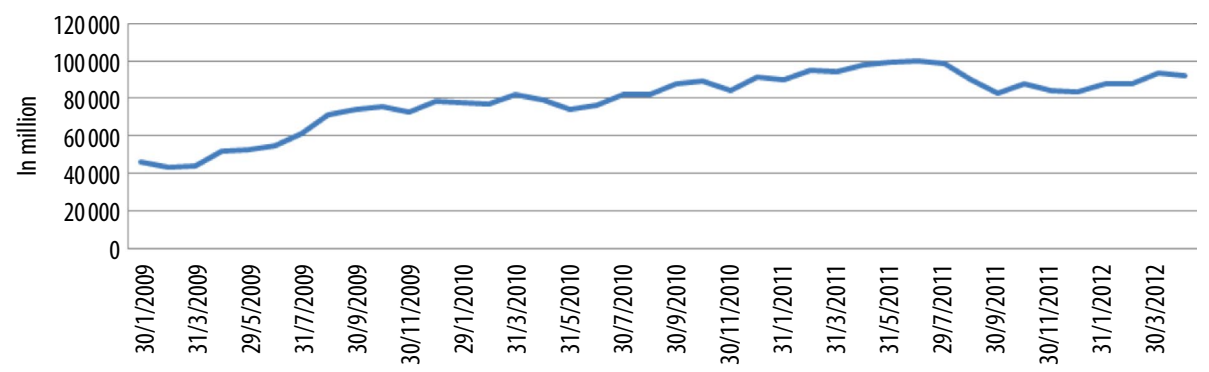

Fig. 2. The market capitalisation of the FTSE/ERPA NAREIT Developed Europe Index Source: DataStream (2012) 
these have clearly demonstrated the significance of European real estate securities as an important tool for institutional investors in their portfolio management. By considering these factors, a specific study of inflation-hedging ability of real estate stocks is a compelling topic for research to enable more informed and practical investment decision-making regarding the role of real estate stocks in a mixed-asset portfolio.

One of the critical issues, however, in the property literature is whether real estate securities exhibit desirable inflation-hedging characteristics in the same manner as direct property investments. To address this issue, academic studies have examined the inflation risk of real estate stocks. Among these studies, the United States (U.S.) securitised real estate market has been widely studied. These studies generally indicate that U.S. REITs provide either no inflation hedge or a perverse inflation hedge in the short run. Similar results are also demonstrated in various European public traded real estate stock markets (Hoesli et al. 1997; Liu et al. 1997; Stevenson 2001; Maurer, Sebastian 2002; Hoesli et al. 2008). Numerous studies have also investigated the long-run hedging properties of real estate stocks by using a cointregration test (Chatrath, Liang 1998; Ganesan, Chiang 1998; Stevenson 2001; Glascock et al. 2002). Nevertheless the test does not guarantee positive relationships among the cointegrated series (Enders 1995). The inconclusive findings suggested there are many issues surrounding the inflation-hedging characteristics of real estate stocks that have not been investigated.

The aim of this study is to explore the shortrun and long-run inflation-hedging properties of European real estate stocks in developed and emerging markets. Specifically this study investigates the following questions:
(1) Do European real estate stocks hedge against inflation in the short run or/and in the long run?

(2) Do European real estate stocks in developed markets behave differently from those in emerging markets in terms of their inflationhedging properties?

By answering these questions, this study will offer contributions to the following areas. First, this study serves as a new test for the institutional involvement hypothesis (Lee, Lee 2012). They postulate that the long-run inflation-hedging properties of real estate stocks are related to the investor composition in the real estate stock markets. Although Lee et al. (2011) showed that real estate stocks in emerging markets do not provide satisfactory inflation-hedging benefits over the long run. But, they did not present any evidence to support that the long-run inflationhedging effectiveness is available in developed markets. Developed markets feature with a higher degree of participation by institutional investors. This is demonstrated by Table 1 .

Table 1 clearly shows that developed markets are characterised with more institutional investors. Specifically, the financial assets of institutional investors in developed markets (i.e. the UK, France and Germany) worth more than USD $\$ 2$ trillion in 2005, whereas the corresponding figures for emerging markets were less than USD \$47billion. It is further supported by the percentage of financial assets held by institutional investors over GDP. In 2005, the percentages ranged from $19 \%$ in the Czech Republic to $207 \%$ in the UK. Overall, these statistics clearly show that the degree of institutionalisation differs markedly between emerging and developed markets.

Importantly, institutional investors would improve the market efficiency since institutional

Table 1. Institutional investors in developed and emerging markets

\begin{tabular}{|c|c|c|c|c|}
\hline \multirow[t]{3}{*}{ Market } & \multicolumn{4}{|c|}{ Financial assets of institutional investors } \\
\hline & \multicolumn{2}{|c|}{ in billion (USD $\$$ ) } & \multicolumn{2}{|c|}{ as a percentage of GDP } \\
\hline & 2000 & 2005 & 2000 & 2005 \\
\hline \multicolumn{5}{|l|}{ Panel A: Developed } \\
\hline France & 1736 & 2310 & 130.7 & 160.2 \\
\hline Germany & 1887 & 2271 & 99.3 & 116.0 \\
\hline United Kingdom & 3051 & 3397 & 210.3 & 207.4 \\
\hline \multicolumn{5}{|l|}{ Panel B: Emerging } \\
\hline Poland & 12 & 47 & 6.8 & 23.6 \\
\hline Czech Republic & 9 & 13 & 16.3 & 19.0 \\
\hline
\end{tabular}

Sources: adopted from Gonnard et al. (2008) and OECD (2012). 
investors tend to attract the analyst's attention. Wang et al. (1995) have found that strong participation from institutional investors will reduce the agency problem and enhance the market efficiency via the increase information production from financial analyst coverage. Moreover, Wiley and Zumpano (2009) also argued that institutional investors are sophisticated investors and they have extensive resources (i.e. research) in making prudent investment decisions compared to individual investors. This is also consistent with the findings of Ziering et al. (1997) and Lee et al. (2008). The authors have found that institutional investors are informed and rational investors. In addition, they have improved information flow and assisted indirect property prices more accurately reflect the performance of underlying real estate.

Emerging markets, on the other hand, are typically characterised by less informed and less rational investors than developed markets (Spyrou 2004). This characteristic makes a direct comparison of the inflation-hedging effectiveness of real estate stocks in developed and emerging markets as a natural laboratory for evaluating the institutional involvement proposition. Therefore, this study will extend the study of Lee et al. (2011) and provide a more complete understanding of the institutional involvement hypothesis. In addition, this current study could provide some insights to investors in the markets where institutional involvement is expected to change.

Second, this study extends our current understanding of the notion of inflation adjustment process that is proposed by Hoesli et al. (2008). Specifically, they asserted that real estate stocks should show strong inflation-hedging ability in the long run. In this study, we find evidence to support the inflation adjustment process hypothesis in which real estate stocks act as a good hedge against inflation in the long run, but also the evidence that different real estate markets have different levels of inflation adjustment speed. Therefore, we found little long-run inflation-hedging effectiveness of real estate stocks in emerging markets in respect to the markets have a slower inflation adjustment speed due to a lower degree of institutional investors' involvement and less transparent information, implying that institutional investors could play a vital role in enhancing the inflationhedging effectiveness of real estate stocks.

Third, we extend the limited long-run inflation-hedging studies of real estate stocks to developed markets and emerging markets in Europe. To the best of our knowledge, this study is the first study that explores explicitly the longrun inflation-hedging properties of real estate stocks in European markets other than the UK and German markets. More importantly, unlike previous studies in Europe; this study employs a dynamic ordinary least squares (DOLS) model to investigate the inflation-hedging characteristics of European property stocks over the long-run for the first time. The advantages of a DOLS model is also discussed by Stock and Watson (1993), Masih and Masih (1996) and Lee and Lee (2012). Hence, this study would offer some important insights to investors who invested in real estate stocks in both developed and emerging markets.

Fourth, an examination and comparison of inflation-hedging features of property stocks in multiple developed and emerging markets will shed additional light on the debate of the differences between developed and emerging property markets. Numerous studies have compared the performance and diversification characteristics between developed and emerging property markets (Barry et al. 1996; Barry, Rodriguez 2004), while there is far less formal attention has been place to the inflation-hedging properties of real estate stocks. This study, therefore, is crucial for investors and policy-makers to further recognise the dissimilarities between emerging and developed property markets.

Lastly, as far as we are aware of, this is the first study on the long-run and short-run inflationhedging effectiveness of real estate stocks in Poland and the Czech Republic. Importantly, the risk of rising inflation is even more apparent in these countries. For instance, the recent annual inflation rates in Poland (3.9\%) and the Czech Republic (3.8\%) were higher than the Euro area (2.7\%) in March 2012 (TradingEconomics 2012). The higher inflation risks in these countries also indicate that inflation hedging is a more critical component for investors in these markets. As such, this study offers some important insights to Polish and Czech investors to improve their investment decision making.

The remainder of this paper is organised as follows. The following section provides a literature review on the inflation-hedging ability of real estate stocks. Section 3 presents data and methodology. Section 4 reports and discusses empirical results. The final section concludes the paper. 


\section{LITERATURE REVIEW}

The effectiveness of real estate securities to serve as inflation hedges has received considerable attention in the property literature. A number of studies have documented the perverse inflation hedge phenomenon of real estate security returns. Gyourko and Linneman (1988) and Park et al. (1990) have offered empirical evidence of US REITs are significantly and negatively related to both expected and unexpected inflation. Yobaccio et al. (1995) showed that US REITs are perverse inflation hedges, even though the impact of stocks has been controlled.

Comparable international evidence was also illustrated by Liu et al. (1997) from 7 real estate security markets (i.e. Australia, France, Japan, South Africa, Switzerland, the UK and the US). Their results revealed either a negative or insignificant relationship between inflation and real estate stock returns. The similar inconclusive results for real estate stocks in the UK were also demonstrated by Hoesli et al. (1997). In Europe, Maurer and Sebastian (2002) evaluated the inflation-hedging properties of real estate stocks in Germany, France, Switzerland and the UK. Consistent with the previous studies, the results indicated that indirect properties in these countries provide either no inflation hedge or a perverse inflation hedge in the short run.

A number of studies have attempted to explain the observed negative relationship between inflation and property stock returns. One of the possible explanations is the proxy hypothesis. This hypothesis was first introduced by Fama (1981) and Geske and Roll (1983) in which the observed anomaly actually reflects the relationships between inflation and other fundamental real activities and monetary policy. Darrat and Glascock (1989) examined the inflation-hedging effectiveness of US REITs, real estate investment and management firms. Their results provided some support for the proxy hypothesis in which a weak relationship between inflation and US real estate stock returns was evident. Nevertheless, the influences of monetary policy and the common stock market have significant lagged effects on current real estate returns. Glascock et al. (2002) further postulated that the perverse inflation puzzle for REITs is merely a manifestation of the effects of changes in monetary policies. Once monetary and other macro variables are controlled, the inverse relation between REIT returns and inflation goes away. Therefore, they argued that the perverse inflation hedge in the REIT market is spurious.
Distinctions are further made between shortrun and long-run relationships. Chatrath and Liang (1998) found that REITs tend to be longterm inflation hedges. Although they did not find any evidence that REIT returns are positively associated with temporary or permanent components of inflation measures in the short run, they found REITs provided an inflation hedge to investors in the long run. Moreover, Ganesan and Chiang (1998) also documented real estate stocks in Hong Kong are cointegrated with inflation. In contrast, little cointegration between real estate stocks and inflation is demonstrated by Stevenson (2001) in 10 international real estate markets. Similar findings are also documented by Glascock et al. (2002). The inconsistent findings could be explained by the flaw of the cointegration test in which it does not guarantee positive relationships among the cointegrated series (Enders 1995).

Few existing studies have explicitly examined the relationship between real estate stock prices and inflation in the short-run and long-run. Hoesli et al. (2008) was the first explicit investigation. They adopted an error correction method to investigate the linkages between inflation, monetary policy, real activity and real estate stocks in the US and UK over 1977-2003. Their empirical tests showed that longer time horizons will result in a positive relationship in accordance with the expected Fisher (1930) relationship. They also asserted that real estate stocks do response to inflation changes through a gradual inflation adjustment process. Therefore, real estate stocks will only show inflation-hedging ability in the long run. More recently, Obereiner and Kurzrock (2012) presented comparable evidence in the German property market. They exhibited that German real estate stocks do provide a hedge against inflation in the long run, although real estate stocks are almost independent from inflation in the short run. The findings support the hypothesis of Lee et al. (1998) in which the Fisher effect only holds in the long run.

Hardin III et al. (2012) provided an alternative explanation to why short-term REIT returns are often negatively related to expected inflation. They attributed this anomaly to inflation illusion. They found that REIT investors suffer with inflation illusion. Importantly, the effect is a short run phenomenon. Eventually, over a long term period, investors correct the stock prices. The findings echo the argument of Piazzesi and Schneider (2008) that stocks can provide a long-term hedge even though in the short-term, there is an inflation illusion effect. 
In extending this line of research, Lee and Lee (2012) compared the inflation hedging features of US REITs before and after the early 1990s. Interestingly, a positive relationship between US REITs and anticipated inflation is only evident in the long run after, though not before, the early 1990s. Importantly, the authors related the inflation-hedging characteristics of REITs to the increase of institutional involvement. Their sizebased results further confirmed the argument of institutional involvement improves the inflationhedging properties of REITs. Therefore, the authors suggested that institutional investors are informed and rational investors and they have improved information flow and assisted REIT prices more accurately reflect the performance of underlying real estate (Ziering et al. 1997; Lee et al. 2008). Lee et al. (2011) further tested the institutional involvement hypothesis with three East Asian emerging markets (i.e. Malaysia, the Philippines and Taiwan). Consistent with the institutional involvement conjecture, they did not find strong evidence to support the notion of real estate stocks hedge against inflation in these markets over the long term.

In summary, several studies have been sought to understand the inflation-hedging characteristics of real estate stocks in the short run and long run, whereas specific studies in emerging markets, particularly emerging markets in Europe are relatively limited. More importantly, the institutional involvement hypothesis is only examined in the US and some Asian emerging markets. Therefore, it is critically important to examine the linkages between inflation-hedging ability and institutional involvement in order to enhance the investment decision making process of institutional investors.

\section{DATA AND METHODOLOGY}

\section{Data}

To assess the inflation-hedging properties of property securities, the total monthly return of European property stocks in three developed and two emerging markets were collected. Three developed markets are the UK, France and German, whereas Poland and the Czech Republic are the two emerging markets ${ }^{1}$. The FTSE EPRA/

\footnotetext{
${ }^{1}$ These five markets were selected in light of the availability of data. Extending this study to other European property markets, particularly emerging markets, is infeasible due to the lack of a comprehensive dataset in other European markets.
}

NAREIT indices for the UK, France and Germany were utilised to present the performances of British, French and German property stocks respectively. The Dow Jones Poland Real Estate Index was employed to measure the performance of Polish property stocks. However, the Czech property stock prices were based on the Czech Republic Real Estate Index. Given the FTSE EPRA/NAREIT indices started only in 1990, this study commenced from Jan 1990 to July 2011. It should be noted that the data for Polish and Czech real estate stocks spanned from February 2005-July 2011 and January 1996-July 2011 respectively due to the limitations of data. Moreover, this study examines the inflation-hedging effectiveness of real estate stocks. Thus it allows us to employ monthly data. Monthly data was widely utilised to analyse the inflation-hedging ability of securitised real estate (i.e. Yobaccio et al. 1995; Maurer, Sebastian 2002; Glascock et al. 2002; Lee et al. 2012).

Consistent with Spyrou (2004) and Lee et al. (2011), industrial production and M2 money supply are proxies of real activities and monetary policies. M2 money supply and industrial production are proxies of real activities and monetary policies. Both variables are controlled in response to Fama (1981) and Geske and Roll (1983) have demonstrated that real activities and monetary policies should be controlled in order to avoid a perverse hedge. Comparable empirical evidence has been documented by Glascock et al. (2002) in US REITs. Specifically, Glascock et al. (2002) have shown that the perverse inflation hedge in the REIT market is spurious. They also attributed it to the failure of controlling real activities and monetary policies in estimating the link between inflation and REITs. Therefore, the industrial production and M2 figures of these 5 markets were also obtained ${ }^{2}$.

Consumer price indices (CPI) were also obtained to measure the inflation rates in these markets. All data were downloaded from DataStream. Following Hoesli et al. (2008), an ARIMA model was utilised to estimate the expected and unexpected inflation indices. To eliminate potential scaling effects, all indices were set at 1.00 for the first month of 1990. The series were also logged for long-run/level analyses and differenced as appropriate (Hoesli et al. 2008). The summary statistics of the indices are presented in Table 2 .

\footnotetext{
${ }^{2}$ Other variables such as interest rate, GDP, employment and industrial output are not included in order to avoid the issue of multicollinearity.
} 
As it can be seen from Table 2, real estate stocks in emerging markets are very volatile in which the standard deviation statistics of the Czech Republic (15\%) and Poland (10.9\%) are considerably higher than the UK (4.5\%), France (4.9\%) and Germany (7.4\%). The results provide some support for the finding of Barry and Rodriguez (2004) that property indices in emerging markets are more volatile than developed markets. Another important observation is the average monthly inflation rates in emerging markets are also relatively higher than developed markets. The figures are consistent with our earlier discussion in which inflation risk is more noticeable in emerging markets compared to developed markets.

A preliminary picture of the inflation-hedging properties of each market, obtained by comparing inflation rates with the average return of real estate stocks for each market, is also shown in Table 2. Results here reveal that real estate stock returns do not move in line with inflation, particularly in emerging markets. Despite higher inflation rates are observed in emerging markets, little evidence of higher returns is found in these markets. This implies that emerging markets offer little inflation-hedging benefits. Nonetheless, the preliminary results should be formally investigated by rigorous tests.

\section{Methodology}

The analysis of this study involves two stages. The first stage is to test the short-run inflation-hedging characteristics of European property stocks. The Fama and Schwert (1977) model was employed to examine the inflation-hedging effectiveness of European real estate stocks over the short run. Subsequently, the linkages between inflation and real estate stock returns in the long run were investigated in the second stage. To assess the linkages, a dynamic ordinary least squares (DOLS) model was carried out.

\section{Fama and Schwert (1977) model}

First, the Fama and Schwert (1977) model was used in this study. The model was based on the Fisher's hypothesis; the expected nominal rate of return is the sum of expected real rate of return and the unexpected inflation. Hence, Fama and Schwert (1977) developed the following empirical model:

$$
R_{t}=\alpha+\beta E\left(\Delta_{t}\right)+\gamma\left[\Delta_{t}-E\left(\Delta_{t}\right)\right]+\varepsilon_{t},
$$

where: $R_{t}$ represents the nominal asset return at the time $t ; E\left(\Delta_{t}\right)$ and $\Delta_{t}-E\left(\Delta_{t}\right)$ are the expected
Table 2. Descriptive summary

\begin{tabular}{|c|c|c|c|c|}
\hline & $\begin{array}{l}\text { Real } \\
\text { estate } \\
\text { stocks }\end{array}$ & $\begin{array}{l}\text { Inflation } \\
\text { rate }\end{array}$ & $\begin{array}{l}\text { Money } \\
\text { supply }\end{array}$ & $\begin{array}{l}\text { Industrial } \\
\text { produc- } \\
\text { tion }\end{array}$ \\
\hline \multicolumn{5}{|c|}{ Panel A: United Kingdom } \\
\hline Mean & 0.414 & 0.192 & 0.383 & 0.008 \\
\hline SD & 4.545 & 0.422 & 4.751 & 0.805 \\
\hline Maximum & 29.275 & 3.300 & 7.557 & 2.266 \\
\hline Minimum & -18.962 & -1.000 & -71.276 & -4.302 \\
\hline \multicolumn{5}{|c|}{ Panel B: France } \\
\hline Mean & 0.890 & 0.143 & 0.390 & -0.017 \\
\hline SD & 4.917 & 0.182 & 1.677 & 3.170 \\
\hline Maximum & 14.427 & 0.800 & 6.887 & 10.997 \\
\hline Minimum & -23.079 & -0.500 & -4.322 & -9.312 \\
\hline \multicolumn{5}{|c|}{ Panel C: Germany } \\
\hline Mean & 0.281 & 0.156 & 0.441 & 0.089 \\
\hline SD & 7.395 & 0.271 & 0.749 & 3.337 \\
\hline Maximum & 34.518 & 1.800 & 4.237 & 11.867 \\
\hline Minimum & -34.509 & -1.600 & -4.906 & -12.017 \\
\hline \multicolumn{5}{|c|}{ Panel D: Poland } \\
\hline Mean & 0.714 & 0.230 & 0.975 & 0.513 \\
\hline SD & 10.892 & 0.348 & 1.032 & 7.075 \\
\hline Maximum & 22.220 & 1.000 & 3.200 & 17.505 \\
\hline Minimum & -36.398 & -0.400 & -1.761 & -13.987 \\
\hline \multicolumn{5}{|c|}{ Panel E: Czech Republic } \\
\hline Mean & -1.353 & 0.296 & 0.575 & 0.315 \\
\hline SD & 15.248 & 0.620 & 0.668 & 2.689 \\
\hline Maximum & 65.316 & 3.979 & 2.741 & 8.092 \\
\hline Minimum & -45.024 & -0.784 & -2.074 & -7.838 \\
\hline
\end{tabular}

Notes: The first two moments (mean and standard deviations) are expressed in percentage form.

and the unanticipated monthly inflation rates respectively in month $t ; \varepsilon_{t}$ is the error term at the time $t ; \beta$ and $\gamma$ are the coefficients to be estimated. An asset is hedged against expected inflation when $\beta>0$, while $\gamma>0$ represents the asset is hedged against unexpected inflation. Based on the arguments of inflation adjustment process (Hoesli et al. 2008) and inflation illusion (Hardin III et al. 2012), it is reasonable to expect little inflationhedging evidence is available from real estate stocks in the short run. In addition, the Fama and Schwert (1977) model is estimated by an OLS.

\section{Dynamic ordinary least squares}

A dynamic ordinary least squares (DOLS) model was undertaken to investigate the inflation-hedging characteristics of European real estate stocks in the long run. The model was proposed by Stock and Watson (1993). As discussed by Masih and Masih (1996) and Bentzen (2004), a DOLS model is more favourable than a number of alternative 
estimators of long-run parameters, including those proposed by Engle and Granger (1987), Johansen (1988) and Phillips and Hansen (1990). Moreover, the distribution of the DOLS estimators is less dispersed and has fewer outliers than the Johansen estimator (Thorbecke 2006). Specifically, the DOLS model allows contemporaneous, lagged, and lead values of differences of the right-hand I(1)-regressors (Stock, Watson 1993; Wooldridge 2003).

Following Glascock et al. (2002) and Hoesli et al. (2008), it is essential to control the real activity and monetary policies in the long run equilibrium. Therefore, inflation, industrial production and monetary policies are included in the long-run relationship with the real estate stocks market. The model can be performed as follows:

$$
\begin{aligned}
& \ln \left(\mathrm{REI}_{t}\right)=\beta_{0}+\beta_{1} \ln \left(\mathrm{EINF}_{t}\right)+ \\
& \beta_{2} \ln \left(\mathrm{UEINFI}_{t}\right)+\beta_{3} \ln \left(\mathrm{MS}_{t}\right)+ \\
& \beta_{4} \ln \left(\mathrm{IPR}_{t}\right)+\sum_{k=-p}^{p} \gamma_{1 k} \Delta \ln \left(\mathrm{EINF}_{t+k}\right)+ \\
& \sum_{k=-p}^{p} \gamma_{2 k} \Delta \ln \left(\mathrm{UEINF}_{t+k}\right)+ \\
& \sum_{k=-p}^{p} \gamma_{3 k} \Delta \ln \left(\mathrm{MS}_{t+k}\right)+ \\
& \sum_{k=-p}^{p} \gamma_{4 k} \Delta \ln \left(\mathrm{IPR}_{t+k}\right)+\xi_{t},
\end{aligned}
$$

where: $\ln ()$ is the natural logarithm; $\mathrm{REI}_{t}$ is the property stock return index at the time $t$; EINFI $_{t}$ and $\mathrm{UEINFI}_{t}$ are expected and unexpected inflation indices at the time $t$ respectively; $\mathrm{MS}_{t}$ is money supply at the time $t$ and $\mathrm{IPR}_{t}$ is industrial production at the time $t$. The optimal leads and lags were selected on the Schwarz's information criterion (SIC). The coefficient of $\beta_{1}$ is expected to be positive, although no a priori sign for $\beta_{2}$ (Porter, $\mathrm{Zhu} 2007)$. It is also hypothesised that a positive sign for $\beta_{4}$, whereas no determinate sign for $\beta_{3}$ due to the pro-cyclicality of monetary policies (Rushid, Kim 2008).

To enhance the creditability of our results, the long-run inflation-hedging properties of common stocks were also carried out. This exercise allows us to compare the inflation-hedging characteristics of real estate stocks and common stocks. The inflation-hedging effectiveness of common stocks can be assessed as follows:

$$
\begin{aligned}
& \ln \left(\mathrm{SMI}_{t}\right)=\beta_{0}+\beta_{1} \ln \left(\mathrm{EINF}_{t}\right)+ \\
& \beta_{2} \ln \left(\mathrm{UEINFI}_{t}\right)+\beta_{3} \ln \left(\mathrm{MS}_{t}\right)+
\end{aligned}
$$

$$
\begin{aligned}
& \beta_{4} \ln \left(\operatorname{IPR}_{t}\right)+\sum_{k=-p}^{p} \gamma_{1 k} \Delta \ln \left(\mathrm{EINF}_{t+k}\right)+ \\
& \sum_{k=-p}^{p} \gamma_{2 k} \Delta \ln \left(\mathrm{UEINF}_{t+k}\right)+ \\
& \sum_{k=-p}^{p} \gamma_{3 k} \Delta \ln \left(\mathrm{MS}_{t+k}\right)+ \\
& \sum_{k=-p}^{p} \gamma_{4 k} \Delta \ln \left(\mathrm{IPR}_{t+k}\right)+\xi_{t},
\end{aligned}
$$

where: $\mathrm{SMI}_{t}$ is the common stocks market index in time $t$.

\section{RESULTS AND DISCUSSION}

\section{Unit-root tests}

To avoid spurious estimation by non-stationary variables, the augmented Dickey-Fuller (ADF) test and the Kwiatkowski-Phillips-Schmidt-Shin (KPSS) (Kwiatkowski et al. 1992) stationary tests were undertaken to assess the stationarity of the series. Following McNown and Wallace (1994), individual time series properties were examined using two alternative tests (ADF and KPSS). The null hypothesis in the ADF test is the presence of a unit root. However, the KPSS test reverses the null and alternative hypotheses. As demonstrated by DeJong et al. (1989), the Dickey-Fuller tests have low power against stable autoregressive alternatives with roots near unity. Therefore, a comparison of the results obtained from the $\mathrm{ADF}$ and KPSS tests can give more insight into the time series properties of the series. If both tests offer similar conclusion, we have more confidence in the stationarity properties of the series (McNown, Wallace 1994). The results are shown in Table 3.

In Panel A, the ADF and KPSS results clearly show that all UK level series contain unit roots and their first differences are stationary, suggesting that these variables will be included in the tests for co-integrating relationship. The series of France, Germany, Poland and the Czech Republic also exhibit a very similar pattern in which all series are I(1). Three variables require comment. Although the German real estate stock return index appears to be $\mathrm{I}(0)$ using the KPSS test, but $\mathrm{I}(1)$ using the ADF test. Mixed results are also found for expected inflation indices for Poland and the Czech Republic. Specifically, both indices are clearly to be I(1) when the series were tested using the ADF tests, whereas the KPSS tests show the series are I(2). To further confirm the stationarity properties of these indices, the Phillip-Person (PP) tests were also conducted for these series. 
Table 3. Unit-root tests

\begin{tabular}{|c|c|c|c|c|}
\hline \multirow[t]{2}{*}{ Market } & \multicolumn{2}{|c|}{ Level series } & \multicolumn{2}{|c|}{ Differenced series } \\
\hline & $\mathrm{ADF}$ & KPSS & $\mathrm{ADF}$ & KPSS \\
\hline \multicolumn{5}{|l|}{ Panel A: United Kingdom } \\
\hline Real estate stock return index & -1.963 & $1.490 * * *$ & $-6.092^{* * *}$ & 0.072 \\
\hline Expected inflation index & 0.545 & $1.872^{* * *}$ & $-3.950 * * *$ & 0.448 \\
\hline Unexpected inflation index & 1.184 & $1.347 * * *$ & $-9.674^{* * *}$ & 0.028 \\
\hline Money supply & -1.646 & $0.321 * *$ & $-15.613^{* * *}$ & 0.107 \\
\hline Industrial production & -1.237 & $0.581^{* *}$ & $-18.897^{* * *}$ & 0.057 \\
\hline \multicolumn{5}{|l|}{ Panel B: France } \\
\hline Real estate stock return index & -0.115 & $1.974^{* * *}$ & $-12.621^{* * *}$ & 0.138 \\
\hline Expected inflation index & $-2.642^{*}$ & $2.009^{* * *}$ & $-13.972^{* * *}$ & 0.145 \\
\hline Unexpected inflation index & -0.984 & $0.355^{* *}$ & $-13.979 * * *$ & 0.201 \\
\hline Money supply & 0.857 & $2.040 * * *$ & $-18.218^{* * *}$ & 0.124 \\
\hline Industrial production & -1.212 & $0.423^{* * *}$ & $-16.120 * * *$ & 0.189 \\
\hline \multicolumn{5}{|l|}{ Panel C: Germany } \\
\hline Real estate stock return index & -1.654 & 0.181 & $-14.430^{* * *}$ & 0.120 \\
\hline Expected inflation index & 1.790 & $2.024^{* * *}$ & $-8.168^{* * *}$ & 0.368 \\
\hline Unexpected inflation index & -1.736 & $0.531^{* *}$ & $-14.571^{* * *}$ & 0.299 \\
\hline Money supply & -1.920 & $2.017 * * *$ & $-5.862^{* * *}$ & 0.358 \\
\hline Industrial production & -1.901 & $0.469^{* *}$ & $-16.542^{* * *}$ & 0.076 \\
\hline \multicolumn{5}{|l|}{ Panel D: Poland } \\
\hline Real estate stock return index & -1.911 & $0.609^{* *}$ & $-6.438^{* * *}$ & 0.300 \\
\hline Expected inflation index & 1.178 & $1.164^{* * *}$ & $-5.958^{* * *}$ & $0.653^{* *}$ \\
\hline Unexpected inflation index & 0.794 & $1.947^{* * *}$ & $-3.127 * *$ & 0.278 \\
\hline Money supply & -2.216 & $1.224^{* * *}$ & $-4.109^{* * *}$ & 0.399 \\
\hline Industrial production & -1.735 & $0.479 * *$ & -2.476 & 0.215 \\
\hline \multicolumn{5}{|l|}{ Panel E: Czech Republic } \\
\hline Real estate stock return index & 0.705 & $0.985^{* * *}$ & $-4.233^{* * *}$ & 0.255 \\
\hline Expected inflation index & -2.980 & $1.602^{* * *}$ & $-4.467^{* * *}$ & $0.391^{* * *}$ \\
\hline Unexpected inflation index & -2.079 & $1.125^{* * *}$ & $-2.543^{* *}$ & 0.185 \\
\hline Money supply & -1.173 & $1.654^{* * *}$ & $-13.146 * * *$ & 0.166 \\
\hline Industrial production & -0.460 & $1.553^{* * *}$ & $-18.921^{* * *}$ & 0.069 \\
\hline
\end{tabular}

Notes: * Rejection of the unit root null hypothesis in the ADF test and the no unit root null hypothesis in the KPSS tests at the $10 \%$ level of significance; ${ }^{* *}$ Rejection of the unit root null hypothesis in the ADF test and the no unit root null hypothesis in the KPSS tests at the $5 \%$ level of significance; *** Rejection of the unit root null hypothesis in the ADF test and the no unit root null hypothesis in the KPSS tests at the $1 \%$ level of significance.

The PP results showed that these series are I(1); thereby we can conclude that all series are stationary at the first difference ${ }^{3}$.

Overall, all variables are I(1) series. Hence the series were further tested for co-integration. The presence of co-integration among the series was assessed using the Johansen and Jeselius (JJ) trace tests series. Results show that real estate stocks, expected and unexpected inflation, real activities and monetary policy are co-integrated. These results are consistent with Glascock et al.

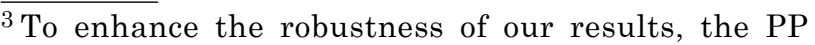
tests were also performed for all series. The results show little variations, reflecting that all variables are stationary at I(1).
}

(2002) and Lee et al. (2011), signifying that these variables are influenced by some unknown common long term economic forces. Thus, controlling the monetary policy and real activities are essential for our long-run equilibriums. Since all of the variables passed the tests for co-integration, the DOLS approach is valid.

\section{Short-run inflation-hedging properties}

This section examines on the inflation-hedging ability of European real estate stocks in the short run. The Fama and Schwert (1977) model was utilised. The results are exhibited in Table 4. 
Table 4. Short-run inflation-hedging effectiveness of real estate stock returns

\begin{tabular}{lllll}
\hline Market & $\alpha$ & $\beta$ & $\gamma$ & $R^{2}$ \\
\hline UK & 0.003 & 1.301 & 1.104 & 0.008 \\
& $(0.407)$ & $(1.109)$ & $(0.647)$ & \\
France & 0.074 & -29.671 & -4.750 & 0.010 \\
& $(1.456)$ & $(-1.126)$ & $(-0.511)$ & \\
Germany & -0.019 & 10.318 & -4.079 & 0.010 \\
& $(-1.304)$ & $(1.615)$ & $(-1.549)$ & \\
Poland & -0.010 & 0.113 & 1.616 & 0.004 \\
& $(-0.281)$ & $(0.386)$ & $(0.504)$ & \\
Czech & 0.004 & -2.219 & -0.592 & 0.022 \\
Republic & $(0.582)$ & $(-1.025)$ & $(-1.369)$ & \\
\hline
\end{tabular}

Notes: This table reports estimated coefficients for the Fama and Schwert test. The model is estimated by

$$
R_{t}=\alpha+\beta E\left(\Delta_{t}\right)+\gamma\left[\Delta_{t}-E\left(\Delta_{t}\right)\right]+\varepsilon_{t},
$$

where: $R_{t}$ presents the nominal asset return at the time $t$; $E\left(\Delta_{t}\right)$ and $\Delta_{t}-E\left(\Delta_{t}\right)$ are the expected and the unanticipated monthly inflation rates respectively for a country in month $t ; \varepsilon_{t}$ is the error term at the time $t$. The NeweyWest produced is used to correct the standard errors for heteroskedasticity and autocorrelation. ${ }^{*}, * *, * * *$ denotes significance at the $10 \%, 5 \%$ and $1 \%$ level respectively.

The results in Table 4 show that irrespective of market, real estate stocks do not appear to act as a good hedge against expected inflation over a short run. The coefficients for the expected inflation index $\left(\beta_{i}\right)$ range from -29.7 to 10.3 . French real estate stocks have the lowest coefficient, whereas German real estate stocks have the highest coefficient. They are all not statistically significant at the $10 \%$ level. Thus, they offer little hedging benefit against expected inflation. Comparable results are also documented for unexpected inflation $\left(\gamma_{i}\right)$ in which insignificant unexpected inflation coefficients are found in all markets. Overall, the results are consistent with those reported in previous studies in which real estate stocks do not exhibit any short-run inflation-hedging characteristics (Hoesli et al. 1997; Hoesli et al. 2008; Stevenson 2001). Given the insignificant relationship between real estate stocks and inflation over the short run, it is not surprising to find low $\mathrm{R}^{2}$ values. Similar results are also found by Liu et al. (1997).

Importantly, the results from Table 4 also offer some indirect support to the view of inflation illusion. Accordingly to Piazzesi and Schneider (2008) and Hardin III et al. (2012), investors could suffer with inflation illusion in the short run, although they will adjust the bias in the long run $^{4}$. Hence, inflation hedging efficiency of real estate stocks should only be documented in the

\footnotetext{
${ }^{4}$ A closer examination of inflation illusion of European real estate stocks is beyond of the scope of this study.
}

long run. This argument is also consistent with the argument of Chatrath and Liang (1998) and Hoesli et al. (2008) in which a long-run relationship that may present between the value of equities and movements in inflation; thereby inflation-hedging efficiency of real estate stocks is presented in the long run.

In summary, this section has clearly shown that European real estate stocks do not act as a good hedge against anticipated and unexpected inflation in the short run. Therefore, it is essential to examine the inflation-hedging effectiveness of real estate stocks in the long run.

\section{Long-run equilibriums}

The preceding section has documented little inflation-hedging ability of European real estate stocks over a short run. Recognising the difference between short-run and long-run, this section examines inflation-hedging characteristics of real estate stocks in the long run. Table 5 reports the inflation-hedging properties of European real estate stocks in the long run. The empirical results are produced by the DOLS model.

As hypothesised, the coefficient of $\ln$ (EINFI), the logarithm of the expected inflation index, in the UK is positive and statistically significant at $1 \%$ level, reflecting that British property stocks are positively responsive to the expected inflation index in the long run. The results are also consistent with the findings of Hoesli et al. (2008) and support the Fisher (1930) hypothesis, which real estate stocks serve as a good hedge against anticipated inflation. Comparable results are also illustrated in the French and German real estate stock markets. Specifically, the expected inflation index coefficients for France and German are positive and statistically significant at $10 \%$, suggesting that France and German real estate stocks offer some protection against expected inflation. The long-run inflation-hedging results also indicate the importance of distinguishing long-run from short-run impacts. The results also support the finding of Hoesli et al. (2008) in which real estate does gradually adjust to changes in inflation though an error correction adjustment process to the long-run relationship. Therefore, it is reasonable to document a positive hedge of real estate stocks in the long run. In addition, the results also offer some indirect support to the view of inflation illusion that is documented by Hardin III et al. (2012) in which real estate stocks are linked to inflation information in the long run. 
Table 5. Long-run inflation-hedging ability of real estate stocks

\begin{tabular}{llllll}
\hline Markets & UK & France & Germany & Poland & Czech Republic \\
\hline Constant & -0.055 & -0.151 & 1.166 & 0.250 & -1.136 \\
& $(-0.767)$ & $(-1.269)$ & $(4.572)$ & $(1.019)$ & $(-2.359)^{* *}$ \\
$\ln ($ EINF) & 1.282 & 2.528 & 5.905 & 16.656 & 2.390 \\
& $(3.450)^{* * *}$ & $(1.735)^{*}$ & $(1.750)^{*}$ & $(0.405)$ & $(0.901)$ \\
$\ln (\mathrm{UEINF})$ & 4.555 & 8.487 & 2.867 & -10.809 & -8.500 \\
& $(3.540)^{* * *}$ & $(2.286)^{* *}$ & $(0.937)$ & $(-0.366)$ & $(-2.130)^{* *}$ \\
$\ln (\mathrm{MS})$ & 0.155 & 1.494 & -2.864 & -1.229 & -4.205 \\
& $(3.645)^{* * *}$ & $(3.275)^{* * *}$ & $(-2.188)^{* * *}$ & $(-0.453)$ & $(-3.218)^{* * *}$ \\
$\ln (\mathrm{IPR})$ & 4.148 & 0.580 & 1.220 & 7.790 & 1.448 \\
& $(6.428)^{* * *}$ & $(2.124)^{* *}$ & $(5.929)^{* * *}$ & $(5.318)^{* * *}$ & $(1.134)$ \\
$R^{2}$ & 0.856 & 0.931 & 0.342 & 0.748 & 0.601 \\
\hline
\end{tabular}

Notes: This table reports estimated coefficients for the DOLS test. The model is estimated by

$\ln \left(R E I_{t}\right)=\beta_{0}+\beta_{1} \ln \left(E I N F_{t}\right)+\beta_{2} \ln \left(U E I N F I_{t}\right)+\beta_{3} \ln \left(M S_{t}\right)+\beta_{4} \ln \left(I P R_{t}\right)+\sum_{k=-p}^{p} \gamma_{1 k} \Delta \ln \left(E I N F_{t+k}\right)+\sum_{k=-p}^{p} \gamma_{2 k} \Delta \ln \left(U E I N F_{t+k}\right)+$ $\sum_{k=-p}^{p} \gamma_{3 k} \Delta \ln \left(M S_{t+k}\right)+\sum_{k=-p}^{p} \gamma_{4 k} \Delta \ln \left(I P R_{t+k}\right)+\xi_{t}$

where: $\ln ()$ is the natural logarithm; $\mathrm{REI}_{t}$ is the property stock return index at the time $t$; EINFI and $_{t} \mathrm{UEINFI}_{t}$ are expected and unexpected inflation indices at the time $t$ respectively; $\mathrm{MS}_{t}$ is money supply at the time $t$ and IPR $_{t}$ is industrial production at the time $t$. Contemporaneous, lagging and leading differences have been included in the equation estimations, although the parameters are not reported. T-values are presented in parentheses. The Newey-West produced is used to correct the standard errors for heteroskedasticity and autocorrelation. *, **, *** denotes significance at the $10 \%, 5 \%$ and $1 \%$ level respectively.

On contrary, a positive and insignificant coefficient of expected inflation is observed in Poland and the Czech Republic. Even though the results from these emerging markets in Europe are consistent with the finding of Lee et al. (2011) from three Asian emerging markets, the above evidence contradicts the results found from British, French and German real estate stocks, implying that investors from Poland and the Czech Republic would receive marginal expected inflation protection by investing in real estate stocks. Importantly the results also suggest that investing in real estate stocks to avoid the expected inflation risk could be a vain exercise for investors from these markets. The long-run inflation-hedging results from emerging markets are at odd with the view of Hoesli et al. (2008), Piazzesi and Schneider (2008) and Hardin III et al. (2012) in which anticipated inflation-hedging should be documented in the long run.

The inconclusive results further highlight the discrepancy between developed and emerging markets. It should be noted that property markets in the UK, France and Germany are developed markets. In reality, these are one of the largest and most active property markets in Europe. As a developed property market, the market has a higher degree of institutional investors' participation. Recently, Devos et al. (2013) have also found that institutional investors prefer mature REITs with lower risk and larger size. Therefore, it appears that real estate stocks in developed markets are much appealing to institutional investors. Furthermore, institutional investors are well informed and more rational investors. Importantly, a more sophisticated investor base improves information flow and facilitates information gathering (Zeiring et al. 1997); thereby investors will able to adjust and respond to inflation stocks in the long run. On the other hand, the Polish and Czech property markets are emerging markets. Given the markets are characterised by less informed and less rational investors, it is not surprisingly to find that investors in emerging markets are unable to react to inflation changes correctly. Moreover, Hoesli et al. (2008) have also found that real estate is different in both the longrun relationship and inflation adjustment process. Coupled with the institutional involvement conjecture as investors are less informed investors in emerging markets, they would have a slower inflation adjustment process; thereby weaker long-run inflation-hedging benefits should be documented in the emerging markets. In short, the mixed results from developed and emerging markets support the view of Lee and Lee (2012) in which inflation-hedging properties are related to institutional investors. Specifically, an enhanced inflation-hedging effectiveness of real estate stocks is observed in an advanced property market. This 
also highlights the institutional involvement is not only related to calendar anomaly puzzles (Lee, Lee 2003; Kohers et al. 2004; Chan et al. 2005), but also to inflation-hedging ability (Lee, Lee 2012).

Another result worth noting is that the coefficients for the unexpected inflation indices. As highlighted by Newell (1996), investors are also concerned with inflation hedging against to unexpected inflation with reference to unexpected inflation is not directly priced into the market. It appears that real estate stocks in developed markets, except Germany, offer a good hedge against unexpected inflation in light of the documented positive and statistically significant unexpected inflation coefficients in Table 4, indicating that real estate stocks in the UK and France can offer some positive hedge against unexpected inflation. In Germany, a positive coefficient is illustrated, whereas it is statistically insignificant, signifying that little hedging ability of German real estate stocks against unexpected inflation in the long run. This could be attributed to a lower degree of institutional involvement in Germany compared to the UK and France. It is clearly demonstrated in Table 1. Westerheide (2006) also found that the German securitised real estate market behaved differently from other markets. He explained that the German market is at a different development stage (low institutional involvement) compared to other developed markets. This is further supported by the figures from the EPRA. As of February 2013, the real estate securities market in Germany is relatively smaller (4\%) compared to the UK (6\%) and France (7\%) (EPRA 2013). Another possible explanation is the extremely low average value of the rate of unexpected inflation (0.009\% per month) in Germany. Importantly, Hoesli et al. (2008) also suggest that the long-run unexpected inflation component should not be of concern if the unexpected inflation rate was low. The mixed results of unexpected inflation are also consistent with previous findings (Stevenson 2001; Maurer, Sebastian 2002). In contrast, in all emerging markets, estimates on the unexpected inflation index are negative, indicating that real estate stocks in these markets do not offer a good hedge against unexpected inflation. Again, the finding further highlights the differences between emerging and developed property markets.

Some interesting observations are noted with regards to the coefficients of the logarithm of money supply. Money supply always features in the models in which a positive and significant coefficient in the UK and French markets. This means that real estate stock investors in the UK and France could benefit from the increase of money supply. The results are consistent with the empirical evidence of previous studies such as Homa and Jaffee (1971) and Darrat and Glascock (1989). However, money supply is negatively related to real estate stocks in other markets. This can be attributed to more pro-cyclical monetary policies in the UK and France (Rushid, Kim 2008). Importantly, the observed difference also implies that British and French real estate stocks are relatively attractive when the general economic climate is poor compared to German, Polish and Czech real estate stocks. Reference to $\ln (\mathrm{IPR})$, the logarithm of industrial production variable, it exhibits that industrial production features in all developed markets, where it is positively and statistically significant related to real estate stock returns. The results support the Fama's (1981) proxy hypothesis and indicate that future economic prospects and business expansion increase the demand of real estate and real estate stocks in these markets. However, no significant coefficient is evident in the Czech Republic. As discussed earlier, developed and emerging markets have significant different characteristics. Hence it is not very surprising to find dissimilar results from developed and emerging markets. The results reported here can be explained in a similar fashion.

Overall, the DOLS empirical evidence clearly provides a broad confirmation of prior empirical and theoretical work in which real estate stocks are linked in the long-run to anticipated inflation. However, comparable evidence is not found in emerging markets, reflecting that the long-run expected inflation-hedging ability of real estate stocks are related to institutional involvement. This supports the hypothesis of Lee and Lee (2012) institutional involvement hypothesis. The finding has some important implications to policy makers and investors in which the involvement of institutional investors is essential. In addition, it should be noted that the results are explicitly generalisation to strong developed markets with a higher degree of institutional investors.

\section{Comparative analysis of general equity stocks}

A comparative analysis of general equity stock returns was also performed. Table 6 presents the DOLS estimates from Equation (3) for common stocks in the five developed and emerging markets. 
Table 6. Long-run inflation-hedging ability of common stocks

\begin{tabular}{llllll}
\hline Markets & UK & France & Germany & Poland & Czech Republic \\
\hline Constant & -0.062 & -0.052 & -0.830 & -0.248 & -0.712 \\
& $(-1.675)$ & $(-0.499)$ & $(-4.734)^{* * *}$ & $(2.156)^{* *}$ & $(-2.968)^{* * *}$ \\
$\ln ($ EINF) & 4.014 & 2.755 & -0.789 & -31.267 & 0.763 \\
& $(14.094)^{* * *}$ & $(2.299)^{* *}$ & $(-0.869)$ & $(-1.286)$ & $(0.813)$ \\
$\ln ($ UEINF) & 5.452 & 8.022 & 4.270 & 27.924 & 0.764 \\
& $(5.739)^{* * *}$ & $(2.357)^{* *}$ & $(4.434)^{* *}$ & $(1.619)$ & $(0.571)$ \\
$\ln (\mathrm{MS})$ & -0.079 & 0.668 & 2.002 & -3.768 & 0.1667 \\
& $(-1.212)$ & $(1.851)^{*}$ & $(5.712)^{* * *}$ & $(-2.388)^{* *}$ & $(0.216)$ \\
$\ln (\mathrm{IPR})$ & 3.132 & 1.751 & 1.504 & 4.197 & 2.835 \\
& $(6.755)^{* * *}$ & $(7.493)^{* * *}$ & $(17.916)^{* * *}$ & $(5.738)^{* * *}$ & $(3.897)^{* * *}$ \\
$R^{2}$ & 0.935 & 0.887 & 0.874 & 0.863 & 0.890 \\
\hline
\end{tabular}

Notes: This table reports estimated coefficients for the DOLS test. The model is estimated by

$\ln \left(\operatorname{Stock}_{t}\right)=\beta_{0}+\beta_{1} \ln \left(\mathrm{EINF}_{t}\right)+\beta_{2} \ln \left(\mathrm{UEINFI}_{t}\right)+\beta_{3} \ln \left(\mathrm{MS}_{t}\right)+\beta_{4} \ln \left(\mathrm{IPR}_{t}\right)+\sum_{k=-p}^{p} \gamma_{1 k} \Delta \ln \left(\mathrm{EINF}_{t+k}\right)+\sum_{k=-p}^{p} \gamma_{2 k} \Delta \ln \left(\mathrm{UEINF}_{t+k}\right)+$ $\sum_{k=-p}^{p} \gamma_{3 k} \Delta \ln \left(\mathrm{MS}_{t+k}\right)+\sum_{k=-p}^{p} \gamma_{4 k} \Delta \ln \left(\mathrm{IPR}_{t+k}\right)+\xi_{t}$,

where: $\ln ()$ is the natural logarithm; Stock $_{t}$ is the common stock return index at the time $t$; EINFI $_{t}$ and UEINFI $_{t}$ are expected and unexpected inflation indices at the time $t$ respectively; MS $_{t}$ is money supply at the time $t$ and IPR is industrial production at the time $t$. Contemporaneous, lagging and leading differences have been included in the equation estimations, although the parameters are not reported. T-values are presented in parentheses. The Newey-West produced is used to correct the standard errors for heteroskedasticity and autocorrelation. * ${ }^{* *}$, *** denotes significance at the $10 \%, 5 \%$ and $1 \%$ level respectively.

By simply comparing the magnitudes of $\beta_{1}$ and $\beta_{2}$ coefficients in Tables 5 and 6 , it is clearly shown that the inflation-hedging performances of common stocks are broadly similar to the real estate stocks. The results are in line with the findings of Hoesli et al. (2008) based on their UK and US results. Nevertheless, no similar evidence is found in Germany. The German results are contrary to the findings in previous section, reflecting that the underlying assets, management behaviours and the structure of firms do have influences on their inflation-hedging abilities (Hoesli et al. 2008). It should be noted that real estate stock returns heavily rely on the performance of the underlying assets. Besides, unlike common stocks, real estate stocks, particularly REITs have less flexibility for management influence such as the high dividend distribution requirement. Therefore, it is not too surprising to find dissimilar results from real estate stocks and common stocks. Importantly, the results imply that German investors view German real estate stocks as a separate asset class. This also highlights the importance of a specific study of real estate stocks. In addition, both common stocks and real estate stocks in the emerging markets do not act as a good hedge against inflation. In reality, both assets are almost independently from anticipated and unexpected inflation rates.

In short, the long-run inflation-hedging efficiency of common stocks, in general, is very comparable to real estate stocks in which it is only documented in developed markets. In other words, the results are broadly supportive to the institutional involvement hypothesis in which developed markets exhibit stronger inflationhedging effectiveness compared to emerging markets in light of a higher degree of institutional investors participation in advanced markets ${ }^{5}$.

\section{Long-run inflation-hedging properties in developed and emerging markets}

To shed more light of the inflation-hedging effectiveness of real estate stocks in developed and emerging markets, the efficiency of developed and emerging real estate stocks is further inspected from a broader point of view. The above results indicate the differing degree of inflation-hedging by different countries, particularly the degree of hedging against inflation is stronger in advanced markets compared to emerging markets. The differences can be attributed to the involvement level of institutional investors in these markets. Whilst this is a possible cause, particularly given the evidence provided earlier in this paper with

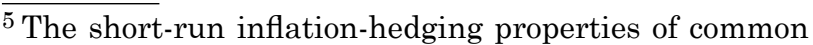
stocks are also investigated by using the Fama and Schwert Model. Again, comparable results are demonstrated in which no significant link between inflation and common stocks. The results are not reported for brevity.
} 
respect to inflation-hedging effectiveness of real estate stocks, the results may just be specific to our sample.

In particular, there is still a critical remaining question of whether the abovementioned results in developed and emerging markets could be generalised to all developed and emerging markets in Europe or the findings are attributed to the sample selection. This is a key issue for investors and one that will enable more informed investment decision making. To address this issue, we revised the Equation (2) in which the FTSE EPRA/NAREIT Developed Europe index and the FTSE ERPA/ NAREIT Emerging Europe index were introduced for developed and emerging markets respectively. The use of two aggregate indices would also overcome the limitation of small sample size for each individual index's computation, particularly in the emerging markets ${ }^{6}$. The modified DOLS model for developed markets can be represented as follows:

$$
\begin{aligned}
& \ln \left(\mathrm{DREI}_{t}\right)=\beta_{0}+\beta_{1} \ln \left(\mathrm{EINF}_{t}\right)+\beta_{2} \ln \left(\mathrm{UEINFI}_{t}\right)+ \\
& \beta_{3} \ln \left(\mathrm{MS}_{t}\right)+\beta_{4} \ln \left(\mathrm{IPR}_{t}\right)+\sum_{k=-p}^{p} \gamma_{1 k} \Delta \ln \left(\mathrm{EINF}_{t+k}\right)+ \\
& \sum_{k=-p}^{p} \gamma_{2 k} \Delta \ln \left(\mathrm{UEINF}_{t+k}\right)+\sum_{k=-p}^{p} \gamma_{3 k} \Delta \ln \left(\mathrm{MS}_{t+k}\right)+ \\
& \sum_{k=-p}^{p} \gamma_{4 k} \Delta \ln \left(\mathrm{IPR}_{t+k}\right)+\xi_{t},
\end{aligned}
$$

where: $\mathrm{DREI}_{t}$ represents the FTSE EPRA/NAREIT Developed Europe index. Given the defined strong inflation-hedging results in developed markets (the UK, France and Germany) in Table 5, it is hypothesised that there should be a positive association between the FTSE ERPA/NAREIT Developed Europe index and British, French and German expected inflation rates.

On the other hand, the inflation-hedging ability of emerging real estate stocks can be estimated as follows:

$$
\begin{aligned}
& \ln \left(\mathrm{EREI}_{t}\right)=\beta_{0}+\beta_{1} \ln \left(\mathrm{EINF}_{t}\right)+\beta_{2} \ln \left(\mathrm{UEINFI}_{t}\right)+ \\
& \beta_{3} \ln \left(\mathrm{MS}_{t}\right)+\beta_{4} \ln \left(\mathrm{IPR}_{t}\right)+\sum_{k=-p}^{p} \gamma_{1 k} \Delta \ln \left(\mathrm{EINF}_{t+k}\right)+
\end{aligned}
$$

6 The property indices in emerging markets are constructed based on a smaller sample size compared to developed markets. This limitation of data should be borne in mind. Therefore, a robustness check based on the FTSE EPRA/NAREIT Developed and Emerging Europe indices will provide alternative results.

$$
\begin{aligned}
& \sum_{k=-p}^{p} \gamma_{2 k} \Delta \ln \left(\mathrm{UEINF}_{t+k}\right)+\sum_{k=-p}^{p} \gamma_{3 k} \Delta \ln \left(\mathrm{MS}_{t+k}\right)+ \\
& \sum_{k=-p}^{p} \gamma_{4 k} \Delta \ln \left(\mathrm{IPR}_{t+k}\right)+\xi_{t}
\end{aligned}
$$

where: EREI $_{t}$ represents the FTSE EPRA/NAREIT Emerging Europe index. Insignificant coefficients of expected and unexpected inflation in emerging markets are expected with respect to the weak inflation-hedging results that are documented in Table 5 for Poland and the Czech Republic.

The initial results from this analysis are reported in Table 7 and the findings for the developed markets, as shown in Panel A, demonstrate that the FTSE EPRA/NAREIT Developed Europe index is positively related to expected inflation in the UK, France and Germany, with a significant and positive coefficient of expected inflation is evident in these markets. The results indicate that the baseline results in Table 5 are robust. In other words, the inflation-hedging effectiveness is more likely documented in a developed market. As discussed earlier, advanced markets are characterised with more institutional investors who are more informed investors. Importantly, the participation of institutional investors would enhance the information flow and assist real estate stocks more accurately to reflect the performance of underlying real estate (Zeiring et el. 1997). In other words, investors in this market can have a faster inflation adjustment process. Therefore it is intuitively appealing to find strong inflationhedging results in these developed markets.

The results reported in Table $7 \mathrm{~B}$ reveal that little link is found between the FTSE EPRA/ NAREIT Emerging Europe index and anticipated and unexpected inflations in Poland and the Czech Republic. Specifically the coefficients of expected and unexpected inflation rates for Poland and the Czech Republic are not statistically significant. The results are expected in light of the weak inflation-hedging features of Polish and Czech real estate stocks that are found in Table 5, confirming that emerging property markets offer little inflation-hedging benefits. This is a similar finding to that reported by Lee et al. (2011) in the three emerging property markets in Asia. The fact that little hedging benefits in emerging markets would also support the explanation is to why institutional investors prefers developed markets that characterised as lower risk, more mature and larger market capitalisation in comparison to emerging markets. 
Table 7A. Long-run inflation-hedging effectiveness of developed real estate stocks

\begin{tabular}{llll}
\hline Market & UK & France & Germany \\
\hline Constant & -0.509 & -0.516 & 0.077 \\
& $(-2.925)^{* * *}$ & $(-1.977)^{* *}$ & $(0.815)$ \\
$\ln (\mathrm{EINF})$ & 1.676 & 4.149 & 13.121 \\
& $(1.991)^{* *}$ & $(1.777)^{*}$ & $(11.777)^{* * *}$ \\
$\ln (\mathrm{UEINF})$ & 17.358 & 12.724 & 0.379 \\
& $(5.800)^{* * *}$ & $(3.118)^{* * * *}$ & $(0.384)$ \\
$\ln (\mathrm{MS})$ & -0.061 & 0.363 & -3.274 \\
& $(0.601)$ & $(0.531)$ & $(-7.632)^{* * *}$ \\
$\ln (\mathrm{IPR})$ & 6.818 & 1.166 & 0.614 \\
& $(5.233)^{* * *}$ & $(3.485)^{* * * *}$ & $(7.123)^{* * *}$ \\
$R^{2}$ & 0.861 & 0.864 & 0.875 \\
\hline
\end{tabular}

Notes: This table reports estimated coefficients for the DOLS test. The model is estimated by

$\ln \left(\mathrm{DREI}_{t}\right)=\beta_{0}+\beta_{1} \ln \left(\mathrm{EINF}_{t}\right)+\beta_{2} \ln \left(\mathrm{UEINFI}_{t}\right)+\beta_{3} \ln \left(\mathrm{MS}_{t}\right)+\beta_{4} \ln \left(\mathrm{IPR}_{t}\right)+\sum_{k=-p}^{p} \gamma_{2 k} \Delta \ln \left(\mathrm{UEINF}_{t+k}\right)+$ $\sum_{k=-p}^{p} \gamma_{3 k} \Delta \ln \left(\mathrm{MS}_{t+k}\right)+\sum_{k=-p}^{p} \gamma_{4 k} \Delta \ln \left(\mathrm{IPR}_{t+k}\right)+\xi_{t}$

where: $\ln ()$ is the natural logarithm; DREI ${ }_{t}$ is the FTSE EPRA/NAREIT Developed Europe index at the time $t$; EINFI $_{t}$ and $\mathrm{UEINFI}_{t}$ are expected and unexpected inflation indices at the time $t$ respectively; $\mathrm{MS}_{t}$ is money supply at the time $t$ and $\mathrm{IPR}_{t}$ is industrial production at the time $t$. Contemporaneous, lagging and leading differences have been included in the equation estimations, although the parameters are not reported. T-values are presented in parentheses. The Newey-West produced is used to correct the standard errors for heteroskedasticity and autocorrelation. *, **, *** denotes significance at the $10 \%, 5 \%$ and $1 \%$ level respectively.

Table 7B. Long-run inflation-hedging effectiveness of emerging real estate stocks

\begin{tabular}{lll}
\hline Market & Poland & Czech Republic \\
\hline Constant & -154.778 & -22.322 \\
& $(-0.096)$ & $(-0.281)$ \\
$\ln (\mathrm{EINF})$ & 44.155 & -2.052 \\
& $(0.088)$ & $(-0.016)$ \\
$\ln (\mathrm{UEINF})$ & 0.796 & 40.441 \\
& $(0.005)$ & $(1.009)$ \\
$\ln (\mathrm{MS})$ & -5.733 & 15.831 \\
& $(-6.311)^{* * *}$ & $(2.759)^{* * *}$ \\
$\ln (\mathrm{IPR})$ & 4.013 & 5.083 \\
& $(2.971)^{* * *}$ & $(4.265)^{* * *}$ \\
$R^{2}$ & 0.953 & 0.822
\end{tabular}

Notes: This table reports estimated coefficients for the DOLS test. The model is estimated by

$\ln \left(\mathrm{EREI}_{t}\right)=\beta_{0}+\beta_{1} \ln \left(\mathrm{EINF}_{t}\right)+\beta_{2} \ln \left(\mathrm{UEINFI}_{t}\right)+\beta_{3} \ln \left(\mathrm{MS}_{t}\right)+\beta_{4} \ln \left(\mathrm{IPR}_{t}\right)+\sum_{k=-p}^{p} \gamma_{2 k} \Delta \ln \left(\mathrm{UEINF}_{t+k}\right)+$ $\sum_{k=-p}^{p} \gamma_{3 k} \Delta \ln \left(\mathrm{MS}_{t+k}\right)+\sum_{k=-p}^{p} \gamma_{4 k} \Delta \ln \left(\mathrm{IPR}_{t+k}\right)+\xi_{t}$

where: $\ln ()$ is the natural logarithm; EREI $_{t}$ is the FTSE EPRA/NAREIT Emerging Europe index at the time $t$; EINFI $_{t}$ and $\mathrm{UEINFI}_{t}$ are expected and unexpected inflation indices at the time $t$ respectively; $\mathrm{MS}_{t}$ is money supply at the time $t$ and $\mathrm{IPR}_{t}$ is industrial production at the time $t$. Contemporaneous, lagging and leading differences have been included in the equation estimations, although the parameters are not reported. T-values are presented in parentheses. The Newey-West produced is used to correct the standard errors for heteroskedasticity and autocorrelation. *,$* *$, *** denotes significance at the $10 \%, 5 \%$ and $1 \%$ level respectively.

Collectively, the inflation-hedging results for the FTSE EPRA/NAREIT Developed and Emerging Europe indices support the view of an enhanced long-run, inflation-hedging result is only presented in developed markets, suggesting that our preceding results in Table 5 is not due to our sample selection. Importantly, the results also further reinforce the notions of (1) the institutional involvement hypothesis (Lee, Lee 2012), (2) a more sophisticated investor base improves information flow and strengths information-gathering process (Badrinath et al. 1995; Ziering et al. 1997; Lee et al. 2008) and (3) the gradual inflation adjustment process in the long run (Hoesli et al. 2008). 


\section{Robustness checks}

To enhance the robustness of the baseline findings, several robustness checks were performed. First, the asymmetric response to inflation was examined in respect to Simpson et al. (2007) have demonstrated the importance of capturing the asymmetric response of US REIT returns to inflation. They posited that US REIT returns do display a negative relationship with inflation. However this is predominantly the case when the inflation of the surprise is negative. The Simpson et al. (2007) approach was performed as follows:

$$
R_{i t}=\alpha+\gamma R_{t-1}+\beta M K T_{t}+\lambda^{+} \pi_{t}^{u+}+\lambda^{-} \pi_{t}^{u-}+\chi^{+} \pi_{t}^{e+}+\chi^{-} \pi_{t}^{e-},
$$

where: $R_{t}$ represents the nominal asset return at the time $t ; \mathrm{MKT}_{t}$ is the market return; $\pi_{t}^{u+}$ is a vector taking on the value of unexpected change in the inflation-related variable when it is positive and zero otherwise; $\pi_{t}^{u-}$ represents a vector that contains the value of the surprise in the inflationrelated variable is negative and zero otherwise; $\pi_{t}^{e+}$ is a vector that contains the value of expected inflation rates if it is positive and zero otherwise and $\pi_{t}^{e-}$ is a vector that contains the value of expected inflation rates when it is negative and zero otherwise. Table 8 presents another perspective of Table 4 by incorporating the asymmetric effects.

Results reveal that European real estate stocks are almost independently from expected and unexpected inflation in respect to the documented insignificant coefficients for both positive and negative expected and unexpected changes in inflation. The results here represent a departure from the finding of Simpson et al. (2007) from US REITs. The differences between Simpson

Table 8. Asymmetric impact of inflation on real estate stock returns

\begin{tabular}{lcl}
\hline Market & Coefficient & $t$-statistics \\
\hline Lag returns & 0.160 & $2.651^{* * *}$ \\
MKT & 0.001 & $4.893^{* * *}$ \\
Unexpected inflation (+) & -0.831 & -0.703 \\
Unexpected inflation (-) & -0.933 & -0.572 \\
Expected inflation (+) & -1.690 & -0.874 \\
Expected inflation $(-)$ & 3.787 & 0.796
\end{tabular}

Notes: This table reports estimated coefficients for a fixed-effect pooled regression that was proposed by Simpson et al. (2007). The model is estimated by

$R_{i t}=\alpha+\gamma R_{t-1}+\beta \mathrm{MKT}_{t}+\lambda^{+} \pi_{t}^{u+}+\lambda^{-} \pi_{t}^{u-}+\chi^{+} \pi_{t}^{e+}+\chi^{-} \pi_{t}^{e-}$.

The White's (1980) produced is used to correct the standard errors for heteroskedasticity. *, **, *** denotes significance at the $10 \%, 5 \%$ and $1 \%$ level respectively. et al. (2007) and this study could be attributed to different markets, highlighting international evidence on the asymmetric response to inflation should be provided. Another reason may simply be the relatively little negative changes in inflation in Europe over the study period, particularly for emerging markets ${ }^{7}$. Overall, results here confirm the preceding findings in which a weak inflationhedging ability of real estate stocks is found in the short run ${ }^{8}$.

Second, one could make a case that comparing the inflation-hedging results of developed markets and emerging markets could incorporate some biases in that different estimation windows were employed. As such, the inflation-hedging effectiveness of British, France, German and Czech real estate stocks was re-estimated based the estimation windows from February 2005 to July 2011. The new estimation window is consistent with the Polish real estate stocks estimation window. The results are displayed in Table 9.

The results exhibit that little inflation-hedging benefit of real estate stocks in the short run, whereas the long-run inflation-hedging characteristic is evident in developed markets. Compared to the results in Table 5, an enhancement of long-run inflation-hedging ability of real estate stocks is evident in developed markets. This offers some further evidence to support that the long-run inflation-hedging properties of real estate stocks are related to the investor composition in the markets. Given the rapid growth of real estate securities in developed markets, it is reasonable to expect a higher institutional investors' involvement in recent years. Therefore, an improved inflationhedging result is observed in these markets. The findings are also consistent with the finding of Lee and Lee (2012) in which a superior long-run inflation-hedging result in US REITs is documented in a more recent study period. Overall, the results

\footnotetext{
${ }^{7}$ It should be noted the Simpson et al. (2007) approach is a fixed-effect pooled regression methodology. In this study, we also utilised random-effect pooled and no effect pooled regressions. However, the results suggest that the baseline results are robust. Simpson et al. (2007) also generalised their models into a time-series analysis. We also performed the time-series regressions for 5 markets. Again, no significant variation is found. The results are available from the authors upon on request.

${ }^{8}$ We also utilised other types of short-run models such as the capital asset pricing model under uncertain inflation (Yobaccio et al. 1995) and the error-correction model (Hoesli et al. 2008). Similar to the Fama and Schwert (1977) model, the unreported results show little inflation hedge ability of real estate stocks in the short run.
} 
Table 9. Inflation-hedging characteristics of real estate stocks over 2005-2011

\begin{tabular}{|c|c|c|c|c|}
\hline Market & UK & France & Germany & Czech Republic \\
\hline \multicolumn{5}{|l|}{ Panel A: Short-run } \\
\hline Constant & $\begin{array}{l}-0.016 \\
(-1.015)\end{array}$ & $\begin{array}{l}0.149 \\
(1.057)\end{array}$ & $\begin{array}{l}-0.100 \\
(-0.792)\end{array}$ & $\begin{array}{l}-0.006 \\
(-1.185)\end{array}$ \\
\hline Expected inflation & $\begin{array}{l}3.912 \\
(0.900)\end{array}$ & $\begin{array}{l}-71.121 \\
(-1.077)\end{array}$ & $\begin{array}{l}46.568 \\
(0.744)\end{array}$ & $\begin{array}{l}0.738 \\
(0.399)\end{array}$ \\
\hline Unexpected inflation & $\begin{array}{l}4.735 \\
(1.119)\end{array}$ & $\begin{array}{l}-14.900 \\
(-0.535)\end{array}$ & $\begin{array}{l}-15.375 \\
(-2.233)^{* *}\end{array}$ & $\begin{array}{l}-0.421 \\
(-0.931)\end{array}$ \\
\hline$R^{2}$ & 0.047 & 0.026 & 0.062 & 0.025 \\
\hline \multicolumn{5}{|l|}{ Panel B: Long run } \\
\hline Constant & $\begin{array}{l}-1.795 \\
(-3.012)^{* * *}\end{array}$ & $\begin{array}{l}0.408 \\
(0.646)\end{array}$ & $\begin{array}{l}4.648 \\
(12.914)^{* * *}\end{array}$ & $\begin{array}{l}-113.305 \\
(-0.493)\end{array}$ \\
\hline $\ln (\mathrm{EINF})$ & $\begin{array}{l}9.052 \\
(4.208)^{* * *}\end{array}$ & $\begin{array}{l}12.549 \\
(2.181)^{* *}\end{array}$ & $\begin{array}{l}22.097 \\
(4.310)^{* * *}\end{array}$ & $\begin{array}{l}134.646 \\
(0.373)\end{array}$ \\
\hline $\ln (\mathrm{UEINF})$ & $\begin{array}{l}0.381 \\
(0.218)\end{array}$ & $\begin{array}{l}-2.003 \\
(-0.316)\end{array}$ & $\begin{array}{l}18.115 \\
(3.262)^{* * *}\end{array}$ & $\begin{array}{l}100.978 \\
(0.971)\end{array}$ \\
\hline $\ln (\mathrm{MS})$ & $\begin{array}{l}-1.508 \\
(-6.534)^{* * *}\end{array}$ & $\begin{array}{l}-2.773 \\
(-1.968)^{*}\end{array}$ & $\begin{array}{l}-11.761 \\
(-7.407)^{* * *}\end{array}$ & $\begin{array}{l}12.941 \\
(0.887)\end{array}$ \\
\hline $\ln (\mathrm{IPR})$ & $\begin{array}{l}3.339 \\
(7.875)^{* * *}\end{array}$ & $\begin{array}{l}0.302 \\
(0.802)\end{array}$ & $\begin{array}{l}0.114 \\
(0.337)\end{array}$ & $\begin{array}{l}1.723 \\
(0.887)\end{array}$ \\
\hline$R^{2}$ & 0.931 & 0.582 & 0.991 & 0.904 \\
\hline
\end{tabular}

Notes: This table reports estimated coefficients for the Fama and Schwert and DOLS tests. T-values are presented in parentheses. The Newey-West produced is used to correct the standard errors for heteroskedasticity and autocorrelation. $*, * *, * * *$ denotes significance at the $10 \%, 5 \%$ and $1 \%$ level respectively.

are comparable to the baseline results, suggesting that the conclusion made earlier with respect to the larger estimation period still hold in general and in particular the institutional involvement is related to the hedging effectiveness of real estate stocks.

\section{CONCLUSIONS AND INVESTMENT IMPLICATIONS}

European real estate stocks have received increasing attention from investors in recent years. Numerous studies have examined the inflationhedging efficiency of European real estate stocks. However, there have been no academic pieces of work dedicated to the impact of institutional investors on the inflation-hedging effectiveness of real estate stocks. This issue can be evaluated by comparing the inflation-hedging properties of real estate stocks in developed and emerging markets. Therefore, this study aims to examine the inflation-hedging properties of real estate stocks in the UK, France, Germany, Poland and the Czech Republic in the short run and long run.

The current study provides a number of important insights. A summary of the inflationhedging characteristics of real estate stocks is also exhibited in Table 10. Firstly, it appears that for real estate stock investors, it is very difficult to hedge the short-run inflation risk with reference to little empirical evidence is found to support the notion of real estate stocks act as a good hedge against inflation in the short run even though the asymmetric effect is controlled. The findings also offer some indirect support to the assertions of (1) Hardin III et al. (2012) that investors suffer with inflation illusion in the short run and (2) Hoesli et al. (2008) inflation adjustment process. Secondly, strong long-run inflation-hedging results of real estate stocks were evident in the UK, France and Germany, suggesting that real estate stocks in these developed markets do serve as a good hedge against expected inflation in the long run. This reflects that real estate stocks in these markets are effective investment vehicles. Thirdly, a comparison of the long-run inflation-hedging effectiveness of real estate stocks in developed and emerging markets find that the degree of hedging against inflation is much stronger in developed markets. Specifically, there is little evidence to support real estate stocks in emerging markets serve as a good hedge against inflation over the long run. The findings support the institutional involvement hypothesis of Lee and Lee (2012) in which a more sophisticated investor base improves information flow and facilitates information gathering (Badrinath et al. 1995; Ziering et al. 1997; Lee et al. 2008); thereby investors will able to anticipate and 
Table 10. Summary of the inflation-hedging properties of real estate stocks

\begin{tabular}{lll}
\hline Market & $\begin{array}{l}\text { Expected } \\
\text { inflation }\end{array}$ & $\begin{array}{l}\text { Unexpected } \\
\text { inflation }\end{array}$ \\
\hline Panel A: Long-run & inflation-hedging & \\
UK & Yes & Yes \\
France & Yes & Yes \\
Germany & Yes & No \\
Poland & No & No \\
Czech Republic & No & No \\
Panel B: Short-run inflation-hedging & \\
UK & No & No \\
France & No & No \\
Germany & No & No \\
Poland & No & No \\
Czech Republic & No & No \\
\hline
\end{tabular}

Notes: This table summarises the inflation-hedging properties of real estate stocks in the short run and long run. The short-run inflation-hedging properties of real estate stocks were examined by the Fama and Schwert (1977) model. On contrary, the long-run inflation-hedging characteristics of real estate stocks were investigated by the DOLS model.

incorporate inflation risk into investment returns in the long run effectively. In contrast, given the emerging markets are characterised with less informed and less sophisticated investors, it is not too surprisingly to find that investors in emerging markets fail to do so.

These findings would have some far-reaching practical implications to real estate stock investors, fund managers and policy makers. First, investors and fund managers should distinguish the impacts of inflation on the short run and long run. Specifically, the results confirm that real estate stock investors may experience lower returns as a result of inflation over the short run, although real estate stocks in developed markets are effective risk management tools to hedge the inflation risk over the long run. Furthermore, investors, particularly international property investors should also aware of the fact that emerging markets not only have different risk and return characteristics (Barry, Rodriguez 2004), but also have dissimilar inflationhedging properties compared to developed markets. The unique inflation-hedging characteristic in emerging markets should also be considered in their investment decision making. Thirdly, policy makers should recognise the importance of institutional investors. Importantly, institutional investors would strengthen the informationgathering process and improve the information flow; thereby the inflation-hedging effectiveness of real estate stocks can be enhanced. Lastly,
European real estate stocks in developed markets are effective investment vehicles in response to the effective inflation-hedging properties over the long run. Therefore, real estate stocks in these markets warrant consideration for inclusion in institutional portfolios. For future research, a comparative study of direct property merits further investigation ${ }^{9}$.

\section{ACKNOWLEDGEMENT}

The authors are grateful to the anonymous reviewers for their valuable comments and suggestions. They also thank the financial support from the European Public Real Estate Association.

\section{REFERENCES}

Bank of England. 2012. Official bank rate, end month [Online]. Available at: http://www.bankofengland. co.uk/boeapps/iadb/Repo.asp?Travel=NIxIRx [accessed 20 April 2012]

Barry, C. B.; Rodriguez, M. 2004. Risk and return characteristics of property indices in emerging markets, Emerging Markets Review 5(2): 131-159. http://dx.doi.org/10.1016/j.ememar.2004.03.001

Barry, C. B.; Rodriguez, M.; Limpscomb, J. 1996. Diversification potential from real estate companies in emerging capital markets, Journal of Real Estate Portfolio Management 2(2): 107-118.

Bentzen, J. 2004. Estimating the rebound effect in US manufacturing energy consumption, Energy Economics 26(1): 123-134. http://dx.doi.org/10.1016/S0140-9883(03)00047-1

Bernanke, B. S.; Woodford, M. 1997. Inflation forecasts and monetary policy, Journal of Money, Credit and Baking 29(4): 653-684.

Badrinath, S. G.; Kale, J. R.; Noe, T. H. 1995. Of shepherds, sheep, and the cross-autocorrelations in equity returns, Review of Financial Studies 8(2): 401-430. http://dx.doi.org/10.1093/rfs/8.2.401

\footnotetext{
$\overline{{ }^{9} \text { We thank }}$ an anonymous referee for this suggestion. This study, however, has an issue of data limitation. It should be noted that no monthly data is available for direct property. The only exception is the UK market. Given that we utilised the monthly data of real estate stocks, a comparative study of direct property is not feasible. In addition, many direct property indices are appraisal based indices. Therefore, the issue of valuation smoothing is inherited in these indices. Yobaccio et al. (1995) also highlighted the importance of using market data instead of appraised indices. Most importantly, little direct property data is available for emerging markets (Czech Republic and Poland). IPD, one of the largest direct property index providers, only offers annual indices to measuring the performance of direct property in Poland and Czech Republic since 2004. Given the relatively short indices history (i.e. actually seven annual returns), it is very hard to conduct a time series analysis of direct property in emerging markets. However, this topic warrants further research.
} 
Chan, S. H.; Leung, W.-K.; Wang, K. 2005. Changes in REIT structure and stock performance: evidence from the monday stock anomaly, Real Estate Economics 33(1): 89-120.

http://dx.doi.org/10.1111/j.1080-8620.2005.00113.x

Chatrath, A.; Liang, Y. 1998. REITs and inflation: a long-run perspective, Journal of Real Estate Research 16(3): 311-325.

Clayton, J.; MacKinnon, G. 2003. The relative importance of stock, bond and real estate factors in explaining REIT returns, Journal of Real Estate Finance and Economics 27(1): 39-60. http://dx.doi.org/10.1023/A:1023607412927

Darrat, A. F.; Glascock, J. L. 1989. Real estate returns, money and fiscal deficits: is the real estate market efficient?, Journal of Real Estate Finance and Economics 2(3): 197-208.

http://dx.doi.org/10.1007/BF00152348

DataStream. 2012. FTSE EPRA/NAREIT DEV Europe $\$$ - Market Value. [Online Database].

DeJong, D. N.; Nankervis, J. C.; Savin, N. E.; Whiteman, C. H. 1989. Integration versus trend stationarity in marcoeconomic time series, Working Paper no 89-99. University of Iowa, Iowa City, US.

Devos, E.; Ong, S. E.; Spieler, A. C.; Tsang, D. 2013. REIT institutional ownership dynamics and the financial crisis, Journal of Real Estate Finance and Economics 47(2): 266-288. http://dx.doi.org/10.1007/s11146-012-9363-2

Enders, W. 1995. Applied econometric time series. New York: John Wiley \& Sons, Inc.

EPRA. 2013. EPRA monthly statistical bulletin: February 2013. Belgium, European Public Real Estate Association.

European Central Bank. 2012. Key ECB interest rates [online]. Available at: http://www.ecb.europa.eu/ stats/monetary/rates/html/index.en.html [accessed 20 April 2012]

Fama, E. F. 1981. Stock returns, real activity, inflation, and money, American Economic Review 71(4): $545-565$.

Fama, E. F.; Schwert, G. W. 1977. Asset returns and inflation, Journal of Financial Economics 5(2): 115146. http://dx.doi.org/10.1016/0304-405X(77)90014-9

Fisher, I. 1930. The thoery of interest. New York: Macmillan.

Ganesan, S.; Chiang, Y. H. 1998. The inflation-hedging characteristics of real estate and financial assets in Hong Kong, Journal of Real Estate Portfolio Managemnet 4(1): 55-67.

Geske, R.; Roll, R. 1983. The fiscal and monetary linkage between stock returns and inflation, Journal of Finance 38(1): 1-33.

http://dx.doi.org/10.1111/j.1540-6261.1983.tb03623.x

Ghosh, C.; Miles, M.; Sirmans, C. F. 1996. Are REITs stocks?, Real Estate Finance 13(3): 46-53.

Glascock, J. L.; Lu, C.; So, R. W. 2002. REIT returns and inflation: perverse or reverse causality effects?, Journal of Real Estate Finance and Economics 24(3): 301-317. http://dx.doi.org/10.1023/A:1015221515787

Gonnard, E.; Kim, E. J.; Ynesta, I. 2008. Recent trends in institutional investors statistics, Financial Market Trends OECD: 1-22.
Gyourko, J.; Linneman, P. 1988. Owner-occupied homes, income-producing properties, and REITs as inflation hedges: empricial findings, Journal of Real Estate Finance and Economics 1(4): 347-372.

http://dx.doi.org/10.1007/BF00187072

Hardin III, W. G.; Jiang, X.; Wu, Z. 2012. REIT stock prices with inflation hedging and illusion, Journal of Real Estate Finance and Economics 45(1): 262-287. http://dx.doi.org/10.1007/s11146-010-9259-y

Hartzell, D. J.; Hekman, J. S.; Miles, M. E. 1987. Real estate returns and inflation, Real Estate Economics 15(1): 617-637. http://dx.doi.org/10.1111/1540-6229.00407

Hoesli, M.; Lizieri, C.; MacGregor, B. 2008. The inflation hedging characteristics of US and UK investments: a multi-factor error correction approach, Journal of Real Estate Finance and Economics 36(2): 183-206. http://dx.doi.org/10.1007/s11146-007-9062-6

Hoesli, M.; MacGregor, B. D.; Matysiak, G.; Nanthakumaran, N. 1997. The short-term inflation-hedging characteristics of U.K. real estate, Journal of Real Estate Finance and Economics 15(1): 27-57. http://dx.doi.org/10.1023/A:1007797221329

Homa, K. E.; Jaffee, D. M. 1971. The supply of money and common stock prices, Journal of Finance 26(5): 1045-1066. http://dx.doi.org/10.1111/j.1540-6261.1971.tb01747.x

Kearns, K.; Rolley, D.; Sarlo, L. 2010. A perspective on inflation and its investment implications [online]. Loomis and Sayles. Available at: http://www. apostleam.com.au/images/stories/pdf/Perspectiveson-InflationLoomis-Sayles.pdf [accessed 3 May 2012]

Kohers, G.; Kohers, N.; Pandey, V.; Kohers, T. 2004. The disappearing day-of-the-week effect in the world's largest equity markets, Applied Economics Letters 11(3): 167-171. http://dx.doi.org/10.1080/1350485042000203797

Kwiatkowski, D.; Phillips, P. C. B.; Schmidt, P.; Shin, Y. 1992. Testing the null hypotehsis of stationarity against the alternative of a unit root: how sure are we that economic time series have a unit root?, Journal of Econometrics 54: 159-178.

http://dx.doi.org/10.1016/0304-4076(92)90104-Y

Lee, C. L.; Stevenson, S.; Lee, M.-L. 2014. Futures trading, spot price volatility and market efficiency: evidence from European real estate securities futures, Journal of Real Estate Finance and Economics 48(2): 299-322. http://dx.doi.org/10.1007/s11146-012-9399-3

Lee, M.-L.; Chiang, K. C. H. 2010. Long-run price behaviour of equity REITs: become more like common stocks after the early 1990s?, Journal of Property Investment and Finance 28(6): 454-465.

http://dx.doi.org/10.1108/14635781011080302

Lee, J.-L.; Clark, C.; Ahn, S. K. 1998. Long- and shortrun Fisher effects: new tests and new results, $A p$ plied Economics 30(1): 113-124. http://dx.doi.org/10.1080/000368498326209

Lee, M.-L.; Lee, M.-T. 2003. Institutional involvement and the REIT January effect over time, Journal of Property Investment and Finance 21(6): 435-449. http://dx.doi.org/10.1108/14635780310508612

Lee, M.-L.; Lee, M.-T.; Chiang, K. C. H. 2008. Real estate risk exposure of equity real estate investment 
trusts, Journal of Real Estate Finance and Economics 36(2): 165-181.

http://dx.doi.org/10.1007/s11146-007-9058-2

Lee, M.-T.; Lee, M.-L. 2012. Long-run inflation-hedging properties of United State equity real estate investment trusts (REITs): before and after the structural break in the 1990s, African Journal of Business Management 6(6): 2162-2168.

http://dx.doi.org/10.5897/AJBM11.1181

Lee, M.-T.; Lee, M.-L.; Lai, F.-T.; Yang, T.-H. 2011. Do real estate stocks hedge inflation in the long run? Evidence from three East Asian emerging markets, Journal of Real Estate Literature 19(2): 347-372.

Liu, C. H.; Hartzell, D. J.; Hoesli, M. H. 1997. International evidence on real estate securities as an inflation hedge, Real Estate Economics 25(2): 193-221. http://dx.doi.org/10.1111/1540-6229.00712

Masih, R.; Masih, A. M. M. 1996. Stock-Watson dynamic OLS (DOLS) and error-correction modelling approaches to estimating long- and short-run elasticities in a demand function: new evidence and methodological implications from an application to the demand for coal in mainland China, Energy Economics 18(4): 315-334.

http://dx.doi.org/10.1016/S0140-9883(96)00016-3

Maurer, R.; Sebastian, S. P. 2002. Inflation risk analysis of European real estate securities, Journal of Real Estate Research 24(1): 47-78.

McNown, R.; Wallace, M. S. 1994. Cointegration tests of the monetary exchnage rate model for three highinflation economies, Journal of Money, Credit and Banking 26(3): 396-411.

Newell, G. 1996. The inflation-hedging characteristics of Australian commercial property: 1984-1995, Journal of Property Finance 7(1): 6-20.

http://dx.doi.org/10.1108/09588689610111593

Obereiner, D.; Kurzrock, B.-M. 2012. Inflation-hedging properties of indirect real estate investments in Germany, Journal of Property Investment and Finance 30(3): 218-240.

http://dx.doi.org/10.1108/14635781211223806

OECD. 2012. OECD StatExtracts, institutional investors' assets [online]. Available at: http://stats.oecd.org/Index.aspx?DataSetCode=7IA [accessed 20 April 2012]

Park, J. Y.; Mullineaux, D. J.; Chew, I. K. 1990. Are REITs inflation hedges?, Journal of Real Estate Finance and Economics 3(1): 91-103. http://dx.doi.org/10.1007/BF00153708

Piazzesi, M.; Schneider, M. 2008. Inflation illusion, credit and asset pricing, in: Campbell, J. Y. (Ed.) Asset prices and monetary policy, Chicago: The University of Chicago Press.

Porter, D. C.; Zhu, J. 2007. Efficient markets, real stock returns and expected inflation: evidence using the Michigan inflation expectation, Journal of International Finance and Economics 7(1): 71-80.

RREEF. 2012. European real estate strategic outlook: March 2012, Frankfurt, RREEF Real Estate, 1-40.

Rushid, M.; Kim, J. H. 2008. In long run relationship between real estate stock return and inflation in
Australia. Paper presented at the 37th Australian conference of economists, 2008 Gold Coast, Queensland, Australia.

Seiler, M. J.; Webb, J. R.; Myer, F. C. N. 2001. Can private real estate portfolios be rebalanced/diversified using equity REIT shares?, Journal of Real Estate Portfolio Management 7(1): 25-41.

Simpson, M. W.; Ramchander, S.; Webb, J. R. 2007. The asymmetric response of equity REIT returns to inflation, Journal of Real Estate Finance and Economics 34(4): 513-529. http://dx.doi.org/10.1007/s11146-007-9023-0

Spyrou, S. I. 2004. Are stocks a good hedge against inflation? Evidence from emerging markets, Applied Economics 36(1): 41-48. http://dx.doi.org/10.1080/0003684042000177189

Stevenson, S. 2001. A re-examination of the inflationhedging ability of real estate securities: empirical tests using international orthogonalized \& hedged data, International Real Estate Review 4(1): 26-42.

Stock, J. H.; Watson, M. 1993. A simple estimator of cointegrating vectors in higher order integrated systems, Econometrica 61(4): 783-820. http://dx.doi.org/10.2307/2951763

Svensson, L. E. O. 1999. Inflation targeting as a monetary policy rule, Journal of Monetary Economics 43(3): 607-654.

http://dx.doi.org/10.1016/S0304-3932(99)00007-0

Thorbecke, W. 2006. How would an appreciation of the renminbi affect the U.S. trade deficit with China?, $B$ E Journal of Macroeconomics 6(3): 1-15. http://dx.doi.org/10.2202/1534-5998.1454

TradingEconomics. 2012. Inflation rates, list by country [online]. Available at: http://www.tradingeconomics. com/ [accessed 20 April 2012]

Westerheide, P. 2006. Cointegration of real estate stocks and REITs with common stocks, bonds and consumer price inflation: an international comparison, Discussion Paper: 06.057, Mannhiem, Germany, Centre for European Economics Research.

Wilson, P. J.; Zurbruegg, R. 2003. International diversification of real estate assets: is it worth it? Evidence from the literature, Journal of Real Estate Literature 11(3): 259-277.

Wooldridge, J. M. 2003. Introductory econometrics: a modern approach. Second edition. Mason, SouthWestern, Thomson Learning.

Yobaccio, E.; Rubens, J. H.; Ketcham, D. C. 1995. The inflation-hedging properties of risk assets: the case of REITs, Journal of Real Estate Research 10(3): 279-296.

Zhang, A., Ewald, C.-O. 2010. Optimal investment for a pension fund under inflation risk, Mathematical Methods of Operations Research 71(2): 353-369. http://dx.doi.org/10.1007/s00186-009-0294-5

Ziering, B.; Winograd, B.; McIntosh, W. 1997. The evolution of public and private market investing in the new real estate capital markets, Parsippany, NJ, Prudential Real Estate Investors. 